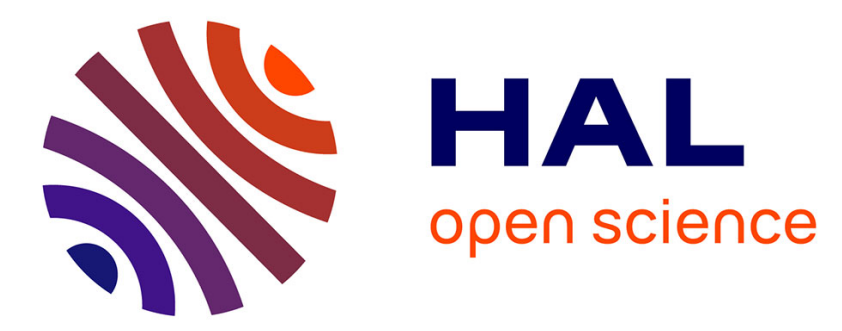

\title{
What Factors Drive transport and Logistics Costs in Africa? \\ Patrick Plane
}

\section{- To cite this version:}

| Patrick Plane. What Factors Drive transport and Logistics Costs in Africa?. 2021. hal-03198081

\section{HAL Id: hal-03198081 \\ https://hal.uca.fr/hal-03198081}

Preprint submitted on 14 Apr 2021

HAL is a multi-disciplinary open access archive for the deposit and dissemination of scientific research documents, whether they are published or not. The documents may come from teaching and research institutions in France or abroad, or from public or private research centers.
L'archive ouverte pluridisciplinaire HAL, est destinée au dépôt et à la diffusion de documents scientifiques de niveau recherche, publiés ou non, émanant des établissements d'enseignement et de recherche français ou étrangers, des laboratoires publics ou privés. 
What Factors Drive Transport and Logistics Costs in Africa?

\author{
Patrick Plane \\ CERDI- CNRS \\ Université Clermont Auvergne (UCA) \\ 63000, Clermont-Ferrand, France
}

September 2020 


\section{Acknowledgments}

The author is grateful to Simone Bertoli, Mohamed Chaffai, Jean-Louis Combes, Clive Gray, Jaime de Melo, Camille da Piedade, Gaël Raballand, and two referees of the Journal for useful comments on an earlier version of this paper. The usual disclaimers apply. Financial support from the Agence Nationale de la Recherche of the French government through the program "Investissements d'avenir "ANR-10-LABX-14-01" is gratefully acknowledged.

E-mail address. Patrick.Plane@uca.fr 


\title{
What Factors Drive Transport and Logistics Costs in Africa?
}

\begin{abstract}
We analyze the domestic transport and logistics costs of importing a 20-foot container into Africa. We run regressions on a panel of 50 African countries for the period 2006-2014 using the RE-2SLS estimator. Distance from port of arrival to the point of delivery is an important explanatory factor of cost. Time-varying variables yield additional and valuable information. For the 2010-2014 sub-period, the simulations suggest that reducing processing times and adjusting real exchange rates to PPP equilibrium levels would save $12 \%$ of the cost to import for North Africa and 37\% for Central Africa.
\end{abstract}

Keywords: Cost of transport and logistics, Africa, physical geography, real exchange rate, transaction costs, rent seeking, processing time.

JEL: L92, 055, H54, N7, N77, R4

\section{Highlights}

- Distance matters in domestic transport and logistics costs in Africa

- Cost to import is sensitive to domestic prices and processing times

- Institutions and organizations are powerful drivers of cost reduction

- Significant cost savings can be achieved through time-varying variables 


\section{What Factors Drive Transport and Logistics Costs in Africa?}

\section{Introduction}

Transport and logistics are a crucial component of competitiveness. In Africa, where these costs account for $15-20 \%$ of the CIF value of imports, they are three to four times higher than elsewhere in the world (Raballand and Teravaninthorn 2009), and are a major obstacle to diversifying the productive base (Alfonso and Vergara, 2019; Eifert et al, 2008; Hoekman and Nicita, 2011). Given the fragmentation of production processes (Feenstra, 1998; Radelet \& Sachs 1998), trade costs strongly influence the profitability of producing tradable goods, thus hampering the emergence of African manufacturing. This is especially true for goods, which are part of global supply chains where each phase of production faces narrow profit margins (Christ and Ferrantino, 2011). Limao and Venables (2001) have established that ground transport costs are 7 times higher per unit of distance than sea transport costs. Sea transport accounts for over $80 \%$ of Africa's external trade. Apart from remoteness from developed economies, many other factors, at seaports as well as along the continent's roads, impede Africa’s competitiveness (see Radelet and Sachs, 1998; Clark, Dollar and Micco 2004; Iwanow and Kirkpatrick, 2009). This paper focuses on the domestic costs of delivering an imported container from its arrival at an African seaport to its final destination.

Our analysis differs on several points from Limao and Venables (2001), who consider total transport and logistics costs, including both maritime and land components. First, we do not take into account the cost of sea transport, which is volatile and depends on factors such as the nature of the good, the port of departure, and the shipping route. Second, we adopt a continent-wide perspective by considering a nearly exhaustive set of African countries for the 
period 2006-2014. Data about costs of importing are from the Trading Across Borders section of the World Bank's Doing Business report (DB). This includes all costs incurred from the landfall seaport to a warehouse in the importing country's capital or principal city (Appendices 1 and 2). For each country, DB identifies a pair of origin and destination cities. In the case of landlocked economies, the fastest and most used transit corridor is considered. On average, if more than $80 \%$ of Africa's exports are in bulk or liquid form, more than $50 \%$ of the continent's imports are containerized.

To the best of our knowledge, transport and logistic costs have not been investigated systematically for Africa as a whole (Appendix 1). Besides the role of physical geography, two time-varying-country-specific factors are considered in our regression models: the real exchange rate level, which captures the impact of relative prices, and the processing time, which is influenced by market failures, organizational failures, or the poor quality of the hard infrastructure. The results show the heterogeneity of costs in Africa. North African countries have lower costs than the other regions, especially Central Africa, where costs are the highest. Distance, measured by kilometers between port of entry and point of delivery, is statistically significant and proves to be the major source of cost differences across countries. Beyond the impact of this geographical factor, transport and logistics are sensitive to relative prices as proxied by the ratio of the Purchasing Power Parity conversion factor to the official exchange rate. Abnormal processing times also influence cost levels (Hummels and Schaur, 2013). Taken together, these two time-varying factors lead to a potential cost saving of US \$ 905 per container for Central Africa. During 2010-2014, avoidable cost ranged from 12\% of import costs for North Africa to 37\% for Central Africa.

The rest of the paper is organized as follows: Section 2 reviews the main factors driving transport and logistics costs in Africa. Section 3 specifies the model and uses econometric regressions to estimate the respective impact of explanatory factors. Section 4 checks the 
robustness of empirical results and simulates potential cost savings by modifying time-varying variables. Section 5 concludes and outlines policy implications of the analysis.

\section{Determinants of transport and logistics cost}

The explanatory variable refers to a 20-foot container containing imported dry cargo weighing 10 tons, with a CIF value of US $\$ 20,000$. The cost of delivering does not take account of tariffs nor sea transport, but includes fees for documents, customs inspection and clearance, customs brokerage, port charges, and inland transport. Two categories of factors cause prices of inland transport and logistics to vary across countries. The literature emphasizes time-invariant factors, largely based on geography. One novelty of this empirical work is to pay attention to time-varying-country-specific determinants.

\section{Factors with low or no variance over time}

Among geographical factors, distance-i.e. kilometers from the gateway port to the delivery point is the most obvious source of heterogeneity across countries. The landlocked situation is also a factor considered in the literature (Arvis, 2010). The most direct route may require more than 1,000 kilometers. The longest continental corridors are between Harare (Zimbabwe) and Durban (South Africa): 1,678 km, Ndjamena (Chad) and Douala (Cameroon): 1,600 km, Kigali (Rwanda) and Dar es Salaam (Tanzania): 1,418 km, Juba (South Sudan) and Mombasa (Kenya): 1,338 km (see Appendix 2). The case of island countries is ambiguous. Small islands generally use a foreign hub for trans-shipment, with feeder vessels conveying the cargo to a national port and conducting customs brokerage and freight forwarding, which increases import cost. Country size and trading volume probably affect the impact of being an island. Limao and Venables (2001) find this feature to be a costreducing factor. Climate may also affect the cost to import with a big difference between the 
arid areas of North Africa and the dense, humid forests of Central Africa. The vector of regional dummies captures this impact.

The quality of the hard infrastructure is also important, and depends on the influence of climate, and public policy through the regular maintenance of the stock and the effectiveness of regulations (e.g. axle load rules) (François and Manchin, 2013). Portugal-Perez and Wilson (2012) raise the point that hard and soft infrastructure complement each other and sometimes self-reinforce in a dynamic process. Creating infrastructure without addressing policy and institutional shortcomings underlying its use, contributes to high transport costs. Maintenance expenditure is generally under-budgeted, and this budget item is often the first to be cut in times of severe financial constraints (see Adam and Bevan, 2014). Infrastructure quality of roads and ports is measured from the components of the World Bank’s Logistics Performance Index (LPI, 2014). The same statistical source is also used to capture the structural efficiency of customs clearance procedures. The low variance over time of this factor goes hand-in-hand with the inertia in customs officers' behavior, which is unlikely to change as quickly as reforms expect. Finally, we test country risk via the Fund for Peace's Fragile States Index (FSI) ${ }^{\mathrm{i}}$. Based on 12 political, social and economic indicators, the FSI combines quantitative information and expert judgment. The higher the index, the greater a country's vulnerability.

\section{Time-varying determinants}

We explore the influence of the Real Exchange Rate (RER), and the Processing time. The RER sheds light on the cost of production as reflected by the cost of living in the economy. It is measured from the Purchasing Power Parity Conversion Factor (PPP CF)- i.e. the number of units of a country's currency required to buy the same amount of goods and services in the domestic market as a U.S. dollar would buy in the United States (c.f. the World Bank's World Development Indicators). For a country $j$ and a year $t$, we divide the PPP CF, expressed in US 
dollars, by the official exchange rate level (NER) of the dollar in the African domestic currency.

$$
R E R j t=(P P P C F / N E R)_{j t}
$$

The departure of the RER from the value 1 tells us to what extent the cost of living differs from that of the United States. In transport terms, the higher this ratio, the more expensive the domestic cost to import a container. Assuming a unique price, and only one tradable good, the ratio shows to what extent the cost of living, i.e. the price of non-tradables, departs from that of the United States. The use of the US dollar as the reference currency allows the calculation of potential production cost differences of transport and logistics services across African countries. Competition level is one reason of cost differences. In some countries, bilateral agreements set quotas for transit freight. While this procedure supports the domestic transporters of landlocked countries, it does it against the interest of the final importer who pays more than he should. According to Raballand and Teravaninthorn (2009), truckers have big profit margins in Central and West Africa, from 60\% to $160 \%$. One of the most expensive corridors is between Ngaoundéré (Cameroon) and Moundou (Chad). Other researchers emphasize the rents received throughout the logistics' chain that benefit shippers and haulers, chambers of commerce, managers of warehouses or dry ports, and customs officials who solicit bribes. Negotiations between stakeholders raise transaction costs. In 2008, along the Tema(Ghana) -Ouagadougou(Burkina Faso) corridor, the average bribe to customs officers on a 20 -foot imported container amounted to $8.2 \%$ of CIF value. Robbery and theft added less than $1 \%$ to cost.

With respect to the time to import, the DB data encompass time spent on customs clearance, inspection, handling, storage at terminals, and transport of a container from landfall port to point of delivery. By processing time, we mean the number of days above 
the "normal" time (i.e. average continental days) required to convey a container from the port to the point of delivery by road. A wide array of factors underlie delivery delays including the quality of roads, weather conditions, congestion, roadblocks, political vulnerability, and border crossing procedures. To break down the time to import of the DB into 2 components, the following econometric method is used. By the regression (2), we assess the impact of the distance $(\theta)$, which is then subtracted to the Time to import of the $D B$ to identify the Processing time (3).

$$
{\text { Processing } \text { time }_{j t}=\text { Time to }_{\text {import }} j t}_{-} \theta \text { Distance }_{j}
$$

\section{Here Table 1}

For two sub-periods, Table 1 provides statistical information about time-varying variables including the cost to import. We divide the 50 African countries into 5 regions with differing numbers of countries. The cost to import depends on the distance and the time the container has to travel. North Africa is at an advantage in this respect as capital cities are close to the port of arrival and the delivery point. This is not the case for West Africa and Southern Africa where a significant percentage of countries are landlocked, 19\% for West Africa and 50\% for Southern Africa, with a capital far from the port of arrival (see Appendix 2). Geography influences the time to import but distance is not the only fact to consider. A continental ranking clearly emerges with Processing times, which account for about 50\% of the time to import. This percentage is consistent with the average of 20 days that Raballand et al (2012) report for the whole continent. For the 2010-2014 period, it takes 34 days to process a container in Central Africa with little change from the previous sub-period, compared to just over 14 days in North Africa. Relative prices may also partly explain differences in cost to import. In Central Africa, real exchange rate levels (RERs) are high, and the cost of living is only 50\% 
lower than in the United States at the official exchange rate, while it is $70 \%$ lower in the middle-income countries of North Africa. ${ }^{\text {ii }}$

\section{Specification of the model and regression results}

By estimating the cost to import (Cjt) on a panel of 50 African countries observed on the 2006-2014 period, we have to take into account heterogeneities across countries and years. The pooled OLS regression neglects the panel character of the dataset. The fixed effects estimator (FE) is an option. Using only the within variation, leads to less-efficient estimation, and an inability to estimate coefficients of time-invariant regressors. The random effects model (RE) is efficient, reducing the variance of estimates of coefficients as long as individual effects are not correlated with the regressors. Processing times are likely to be problematic. Bribes affect Processing times in different ways according to importers who strive to limit time spent with customs officials and other uniformed personnel (Hallward-Driemeier and Pritchett, 2015; Freund, Hallward-Driemeier, and Rijkers, 2014). If Processing times depend on importers' willingness to pay, the aforementioned estimators (OLS, FE, RE) are biased, none of them providing information about causal relationships. The Hausman-Wu (1978) test did not reject the presence of endogeneity. Table 2 presents the main empirical results by considering the broadest specification of the model.The linear form simplifies economic interpretation of regression coefficients, and log-log or semi-log specifications did not provide better fits. Equation (4) is the random effect estimator that proved to be the most appropriate. Subscripts $j$ and $t$ are country and year, respectively.

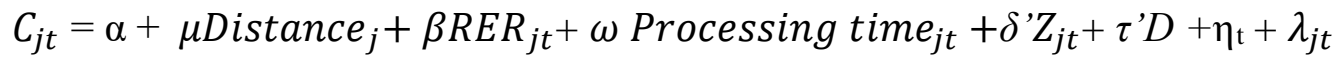

$j=1 \ldots 50$, and $t=2006 \ldots 2014$, with $\lambda_{j t}=\gamma_{j}+\varepsilon_{\mathrm{jt}}$ 
Beside RER and Processing time, because of the dominant impact on the dependent variable, we separate Distance (i.e. kilometers) from the Z-vector of other determinants with a limited time variance: infrastructure, customs, and Fragile States Index. D is the matrix of dummy variables for regions, landlocked, island; $\alpha$ is the intercept; $\eta_{\mathrm{t}}$ are year fixed effects; $\lambda_{j t}$ is the error term with $\gamma_{j}$ specific effects by country, uncorrelated with the independent variables; and $\varepsilon_{j t}$ is the idiosyncratic error. In other words:

$$
E\left(\gamma_{j}\right)=E\left(\varepsilon_{j t}\right)=0 ; E\left(X^{\prime} \gamma_{j}\right)=E\left(X^{\prime} \varepsilon_{j t}\right)=0 \text {; and } E\left(\lambda_{j t}, \text { Processing time } \text { tim }_{j}\right) \neq 0 \text {. }
$$

To get an unbiased coefficient for Processing time, we use 3 instruments which meet the exclusion restriction. Population size is correlated with infrastructure quality and port economies of scale. Jedwab and Storeygard (2017) find that large African countries build relatively more infrastructure in order to improve internal communication. Correlation with cost to import is only indirect, through the productivity effect. We add 2 instruments, not correlated with each other, that reflect the role of institutions. The longer it takes to resolve insolvency of firms, the longer the time required to manage containers. We also introduce the processing time of bordering countries. By using this variable, adjusted for the distance impact, we hypothesize that sub-regional behavior is similar to the characteristics of logistics in the country under study. For landlocked economies, to prevent direct correlation with $C_{j t}$ we remove the transit country from the list of neighbors. ${ }^{\text {iii }}$

\section{Here Table 2}

In Table 2, the Hausman test between the FE and RE estimators does not reject the hypothesis that the variations across countries are random, uncorrelated with the regressors. In this case, the RE-2SLS is the most efficient (Reg 6), the instrumented regression about the Processing time being given in Table 3. Table 2 shows that 5 variables are statistically relevant including 
the 2 time-varying variables: RER and Processing time. If the dominant impact of distance is shown, the island characteristic also matters. The regional dummy for Central Africa varies from the average regression result with an extra cost estimated at about 1,000 US dollars. More comments about the coefficients of the main variables are provided with the parsimonious specification (Table 3). For now, let us observe that some variables, such as the landlocked characteristic, are not significant.

Prima facie, when we account for distance variation across countries, the "border effect", which is collinear with the landlocked feature, no country has more than one border to cross, is not as costly as generally assumed (Limao and Venables 2001, Christ and Ferrantino, 2011). However, this result has to be qualified. The correlation with Processing time may explain the non-significance of the landlocked coefficient. A long trip and a border crossing generate uncertainty and dispersion around the conventional costs and time that the DB hypothesizes. The Abidjan-Ouagadougou corridor illustrates the dispersion of costs interacting with import time. In 2016, the Conseil Burkinabé des Chargeurs evaluated the average time at 17 days, within a range of 5 to 32 days. This includes 1 to 18 days for document preparation, customs clearance, inspection, and port and terminal handling; 2 to 8 days for land transport; and 2 to 6 days for container processing. To some extent, the DB ignores this dispersion effect, which may particularly impact landlocked economies. No specific contribution arises in the explanation of the dependent variable with the 3 following variables: Infrastructure, customs services, and the Fragile State Index (FSI). We may assume that Processing time captures the impact of these phenomena.

Table 3 focuses on the parsimonious empirical model that only accounts for statistically significant variables (Reg 7). Based on the F-test, we keep regional and year dummies to identify non-observable heterogeneities. The first stage regression of the RE-2SLS estimator is proposed on the right-hand side. The set of instruments proves significant. The F-value of 
this first stage regression is 78.2, far above the threshold of 10 for weak instruments (Stock and Yogo, 2005). In addition, the Sargan test of overidentifying restrictions does not reject the null hypothesis, which means that our instruments are adequate. In the cost to import regression, distance remains a major component. The coefficient yields a marginal cost 16.8 US cents per ton-kilometer, higher than reported in previous African case studies. However, the DB assumes a container with a 10-ton load. Most container are more heavily loaded. For example, on the Dakar (Senegal)-Bamako (Mali) corridor, rice containers vary between 20 and 25 tons (ADB, 2015), which makes for a big difference between the DB convention and actual values (Hallward-Driemeier and Prichett, 2015). Per ton-kilometer, the market price for standard products varies from 4 US cents in Kenya and Zambia (close to the price in European and Asian countries), to 11-15 US cents in some landlocked countries, such as Burundi, Chad, Central African Republic and Niger (Raballand and Teravaninthorn, 2009; Gwilliam, 2011; Osborne, Pachon and Araya, 2014). If we raise the 10-ton load to 20 tons, the coefficient is about 8.4 US cents per ton-kilometer, close to what Raballand and Teravaninthorn (2009) observe. Being an island is a cost saving characteristic of US \$580. Nonetheless, it is important to be careful in interpreting this coefficient. The sub-sample of islands is a small one, and $71 \%$ of observations are for middle-income countries, a distribution that differs from the per capita income criterion for the whole continent (51\%).

\section{Table 3 here}

Given the Processing time coefficient, the marginal cost of an extra day is US \$33.9. It means that over the period 2010-2014, the average cost of Processing time ranges from US \$498 per TEU in North Africa (33.91x14.7) to US \$1,272 in Central Africa (33.91x37.5). Within the latter group, in Chad, in 2014 it took 55 days to comply with formalities and overcome hurdles along the Douala-Ndjamena corridor. The resulting cost was US $\$ 1,865$. 
What about the impact of the real exchange rate? RER ranges between 0 and 1 . The upper limit means that, at the official exchange rate, the local currency's purchasing power equals that of the US dollar in the United States. In other words, assuming similar productivity levels between 2 African countries, Reg 7, Table 3 shows that a difference of $20 \%$ in the RER means an additional import cost of US \$311 $(0.2 \times 1,557)$.

\section{Robustness checks and policy implications}

So far, some institutional factors, whose impact is qualitative and difficult to measure, have been left aside. This is the case of the property rights structure, especially the influence of the private management of public services, and the market competitive pressure. Although the Hausman test did not reveal a specific problem in that respect, omitted variables could affect the coefficient of time-varying variables. Regression results may also be sensitive to regions, or per capita income levels heterogeneities (Appendix 1). Finally, under the hypothesis that empirical results prove robust, in what proportion is it possible to reduce the cost to import by modifying the RER or the Processing time?

\section{Assessing the impact of institutional reforms}

Four private international operators manage port terminals over the continent. Bolloré, the leader in transport and logistics, combines a wide range of services and promotes a doorto-door strategy, from maritime shipment to warehouse delivery. Competing firms are also moving to multimodal services (APM, MSC, CMA-CGM). In 2014, while private firms had already long-standing involvement in the management of port terminal activities (Tanzania, Cameroon, Côte d'Ivoire and Egypt), very few African countries did not trust in the private operators yet (South Africa, Namibia, Sudan, Mauritius, etc.).

We define several variables reflecting institutional changes: (i) First, we differentiate countries according to whether they have a private port operator. For a long time, pilotage, 
towing, mooring, dredging, and cargo handling were a public monopoly. In this context, a wide array of stakeholders colludes to extract rents pushing the cost of services up. A private operator is expected to cut these economic inefficiencies. (ii) Second, we ask whether the number of years of private management makes prices lower keeping in mind that the port is only one segment of the domestic cost to import. Door-to-door services are quite limited. Private international operators are far from providing integrated services on the whole transport and logistic chain. (iii) Third, we conduct a before/after analysis by restricting the sample to countries that awarded, during the period, a concession contract for the port to a private group. (iv) Finally, we test direct and indirect competition by introducing the number of port terminal operators and the presence of a railway. Along a corridor, competition and/or complementarity between rail and road may optimize freight movement and reduce costs. Rail is a safer mode of transport because it is not subject to unexpected charges such as roadblocks. Rail transport is less expensive than road at market prices and even more when economic prices are considered, i.e. taking into account externalities. Multimodal transport can be an option but is penalized by additional fixed costs resulting from loading and reloading activities. $^{\text {iv }}$

Of these additional variables, only the number of years of private management is significant with a counter-intuitive sign (Reg 9). Several reasons may underlie this result. First, private port services are only one component of the cost to import. No clear conclusion arises without breaking down the cost into port and road services. Secondly, regulatory agencies may have failed to promote fair sharing of economic surplus between consumers and producers. In this case, the private firm maintains high prices and captures the efficiency gains to accelerate its investment payback. Finally, there is a possibility, of a more optimistic interpretation that we cannot check - higher prices of transport and logistics are positively correlated with a higher quality of service. 


\section{Table 4 here}

\section{Sensitivity of regression results to sample size}

To examine the heterogeneity of slope coefficients, we rerun regression 7 (Table 3), by modifying the sample size. First, we separate middle- from low-income countries (Appendix 1). We conduct a second sensitivity test by eliminating income distribution tails. This means dropping North African countries from the sample. Due to being close to Europe, these countries are more integrated into global value chains, and their costs are more subject to competitive pressure. Then we also drop Central African countries, which suffer from the strong influence of geographical variables.

\section{Table 5 here}

Table 5 shows that regression coefficients remain quite stable across per capita income categories. This is especially true of public policy variables (RER and Processing time) that can change import costs quickly. A similar outcome occurs when we remove the tails of the statistical distribution.

\section{Simulation of potential cost savings}

In the short-to-medium term, one way to reduce transport and logistics prices is to push up direct and indirect competition. For landlocked economies strengthening the competitive market structure proves beneficial in East Africa (Kunaka, Raballand, Fitzmaurice, 2016). In Congo (RDC), the use of the Luanda (Angola)-Kinshasa (RDC) corridor as an alternative to the traditional corridor from the national port of Matadi also reduces prices and profit margins. An alternative or a complementary channel to influence prices is to change RERs and/or processing times to appropriate levels. For the RER, let us consider Balassa (1964) and 
Samuelson (1964)'s argument, which assumes that the lower the level of development the lower the price of non-tradables. In other words, the price of domestic transport and logistics increases as the productivity level rises in the tradable sector as measured by the per capita income. Although the empirical sample is not worldwide, African countries are not homogenous with respect to the per capita income level. In addition, some of them benefit from rents, and the GDP clearly overestimates the true productivity level to implement the diversification of the productive base. Equatorial Guinea is an extreme case. Its per capita GDP in 2007 was close to that of Greece and Portugal because of high rents from exported oil and gas. Accordingly, we make a double correction to assess the cost savings that may result from an adequate $R E R$. First, we subtract natural resource rents from the GDP at current prices in US dollars, and then we adjust RER levels to account for the impact of the productivity bias.

For country $j$ and product $k$ (i.e. oil, natural gas, coal, minerals, and forest products), the World Bank defines the percentage of rents as the difference between world market price $\left(P_{k t}\right)$ and domestic average cost $\left(C M_{j k t}\right)$. We weight these differences by product $k$ 's contribution to GDP in year $t$, giving the percentage of rents in domestic activity, which is denoted $\left(\theta_{j t}\right)$.

$$
\text { With } \theta_{j t}=\sum_{k=1}^{n}\left(P_{k t}-C M_{j k t}\right) \mu_{j k t} \quad \theta_{j} \in[0,1]
$$

Taking 190 countries over the period 2006-2014, we regress the real exchange rate (RER), i.e. Price level ratio of PPP conversion factor (PPP CF) to the official exchange rate (NER), on the productivity indicator (Appendix 3). From equations (6) and (7), we estimate the impact of relative prices via the difference or misalignment (MIS), between the actual $R E R$ and the Balassa-Samuelson adjusted rate (Rodrik, 2008). Calculation is based on the information delivered by the FERDI Sustainable Competitiveness Observatory (SCO) (see: 
https://competitivite.ferdi.fr/) and the information of the World Development Indicators of the World Bank.

$$
\begin{gathered}
R E R j t=(P P P C F / N E R)_{j t}=\alpha+\sigma *\left(\left(1-\theta_{j t}\right) * \text { per cap GDP } P_{j t}\right)+u_{j t} \\
M I S_{j t}=\left(R E R_{j t}-\widehat{R E R_{j t}}\right)
\end{gathered}
$$

Now moving to the Processing time, for each country, we compare it to a reference value corresponding, for each sub-period, to the distribution's fourth quintile (i.e., 13.75 days for 2006-10 and 7.18 days for 2010-14). This African quintile is realistic, achieved by 17 countries at least once during the 2006-2014 period. For countries, whose performance is better than the reference value, we keep national figures.

Import cost savings $_{j t}=v\left[M I S_{j t}\right]+\chi\left[\right.$ Processing Time $_{j t}-$ Processing Time $\left.\left._{(r e f}\right)\right]$

\section{Table 6 here}

In Table 6, potential cost savings are in US \$ and percentages of the price paid. Information is provided by sub-region, and for each of them we mention the country having the most to earn, in all cases around 50\% of the price paid (Appendix 4). For expression (8), regression coefficients for Processing time and the RER are from Reg 7, Table 3. For the period 20102014, Central Africa has the most to gain, especially DR Congo (US \$1,591, 43\%). West Africa and Southern Africa follow with potential cost savings of about US \$ 500. Northern Africa logically has less to save. These countries are the continental reference although they do not reflect the best worldwide state of art for transport and logistics services. These calculations inspire two comments. First, in each sub-region the least efficient country is coastal, relativizing the border effect argument. Second, container processing times account for more than $90 \%$ of the potential cost saving. However, for some countries, the impact of 
real exchange rates adjustments is not negligible. For Angola, over the most recent period, the misalignment of the RER accounts for $25 \%$ of the potential gain $(357 / 1,156)$.

\section{Concluding remarks}

High domestic transport and logistics costs impede African countries’ ability to diversify and participate in global value chains. However, the situation is far from homogeneous across Africa. These services in Central Africa are expensive compared to those in middle-income North African countries. Geographical remoteness, market failure, and weak institutions, bear the responsibility for these excessive costs. The paper has focused attention on 2 time-varying factors, 2 non-exclusive options to improve competitiveness of transport and logistics services. The first avenue is through the exchange rate policy that reduces the relative price of non-tradable goods. The second avenue, which may interact with the previous one, is to have more efficient processing times in the spirit of the Trade Facilitation Agreement (WTO, 2017).

Our analysis yields a set of main empirical conclusions. First, after accounting for distance, landlocked status is not statistically significant. No country crossing more than one border, being landlocked correlates perfectly with the border effect. Second, hidden transaction costs reflected in the processing time offer the greatest opportunity for reducing costs, on average $90 \%$ of the effective domestic cost. All things being equal, an additional day in delivery costs about US \$34 per container. Third, relative prices have a limited impact, except for some countries where raw material rents are a source of price distortion. Angola, a costal country with one of Africa's highest transport and logistics costs, illustrates this phenomenon. Fourth, cost to import does not prove sensitive to the number and the presence of private operators in port terminals. More work is needed to refine this last conclusion, which does not take account of the quality of services. 
Table 1. Domestic transport and logistics costs in Africa: time-varying variables

\begin{tabular}{|l|c|c|c|c|c|c|}
\hline \multirow{2}{*}{} & \multicolumn{2}{|c|}{ Mean } & \multicolumn{2}{c|}{ Median } & \multicolumn{2}{c|}{ Standard deviation } \\
\cline { 2 - 7 } & $2006-2010$ & $2010-2014$ & $2006-2010$ & $2010-2014$ & $2006-2014$ & $2006-2014$ \\
\hline North Africa (4) & & & & & & \\
Cost to import & 1,087 & 985.6 & 1,000 & 915 & 352.5 & 212.9 \\
Time to import & 23.2 & 18.6 & 22.5 & 17 & 4.70 & 4.419 \\
Processing time & 19.3 & 14.7 & 21.7 & 14.4 & 6.5 & 7.6 \\
RER & 0.32 & 0.32 & 0.34 & 0.32 & 0.19 & 0.05 \\
\hline West Africa (16) & & & & & & \\
Cost to import & $1,723.1$ & $1,910.7$ & $1,363.0$ & $1,521.5$ & 882.2 & $1,001.6$ \\
Time to import & 37.8 & 32.8 & 35.0 & 32.0 & 13.9 & 12.1 \\
Processing time & 32.5 & 27.5 & 31.7 & 28.8 & 9.1 & 9.2 \\
RER & 0.38 & 0.41 & 0.38 & 0.41 & 0.07 & 0.06 \\
\hline East Africa (14) & & & & & & \\
Cost to import & $2,080.0$ & $2,236.3$ & 1,815 & 1,925 & $1,194.4$ & $1,272.6$ \\
Time to import & 39.9 & 30.5 & 36.0 & 28.0 & 20.5 & 12.5 \\
Processing time & 25.8 & 16.4 & 24.4 & 17.7 & 13.2 & 9.6 \\
RER & 0.38 & 0.39 & 0.38 & 0.38 & 0.09 & .077 \\
\hline Central Africa (8) & & & & & & \\
Cost to import & $2,809.2$ & $3,852.9$ & $2,201.0$ & $2,625.0$ & $1,704.0$ & $2,695.5$ \\
Time to import & 52.5 & 50.5 & 53.5 & 49.5 & 24.9 & 24.9 \\
Processing time & 39.4 & 37.5 & 37.2 & 34.1 & 13.3 & 13.8 \\
RER & 0.46 & 0.479 & 0.45 & 0.47 & 0.07 & 0.06 \\
\hline Southern Africa (8) & & & & & & \\
Cost to import & $2,243.37$ & $3,084.25$ & 1,950 & 2,482 & 845.74 & $1,544.901$ \\
Time to import & 45.47 & 40.9 & 46 & 36.0 & 15.9 & 16.8 \\
Processing time & 26.7 & 22.1 & 21.5 & 20.0 & 14.4 & 12.5 \\
RER & 0.44 & 0.47 & 0.44 & 0.46 & 0.08 & 0.09 \\
\hline B. For the sort
\end{tabular}

N.B. For the sources and for no-time-varying variables, see Appendix 2. Processing time is calculated as mentioned in section 2, relations (2) and (3). On the left hand side column, in bold characters the number of countries is indicated for each region. The Cost to import, -i.e. the dependent variable, refers to a container and is expressed in US dollars. Time to import and Processing time are expressed in days. RER is defined on the interval (0-1). 
Table 2. Regression results of transport and logistics costs in Africa (2006-2014)

\begin{tabular}{|c|c|c|c|c|c|c|}
\hline & $\begin{array}{c}\text { Reg } 1 \\
\text { OLS }\end{array}$ & $\begin{array}{c}\text { Reg } 2 \\
\text { FE }\end{array}$ & $\begin{array}{c}\operatorname{Reg} 3 \\
\text { RE }\end{array}$ & $\begin{array}{l}\operatorname{Reg} 4 \\
\text { 2SLS } \\
\end{array}$ & $\begin{array}{c}\text { Reg } 5 \\
\text { FE 2SLS } \\
\end{array}$ & $\begin{array}{c}\operatorname{Reg} 6 \\
\text { RE 2SLS } \\
\end{array}$ \\
\hline Distance & $\begin{array}{c}3.040 * * * \\
(0.332)\end{array}$ & & $\begin{array}{c}3.200 * * * \\
(0.876)\end{array}$ & $\begin{array}{c}2.557 * * * \\
(0.404)\end{array}$ & & $\begin{array}{c}2.693 * * * \\
(0.868)\end{array}$ \\
\hline RER & $\begin{array}{c}1,532 * * * \\
(534.1)\end{array}$ & $\begin{array}{l}1,184^{*} \\
(627.8)\end{array}$ & $\begin{array}{c}1,458 * * \\
(606.9)\end{array}$ & $\begin{array}{c}1,189 * * \\
(573.5)\end{array}$ & $\begin{array}{l}1,160 * \\
(682.5)\end{array}$ & $\begin{array}{c}1,366^{* *} \\
(644.9)\end{array}$ \\
\hline Processing time & $\begin{array}{c}26.77 * * * \\
(3.381)\end{array}$ & $\begin{array}{c}-0.519 \\
(3.979)\end{array}$ & $\begin{array}{l}7.264 * \\
(3.792)\end{array}$ & $\begin{array}{c}44.85 * * * \\
(8.711)\end{array}$ & $\begin{array}{c}30.38 \\
(25.17)\end{array}$ & $\begin{array}{c}32.84 * * \\
(15.83)\end{array}$ \\
\hline Island & $\begin{array}{c}-533.4 * * * \\
(155.4)\end{array}$ & & $\begin{array}{c}-1,085^{* * * *} \\
(382.9)\end{array}$ & $\begin{array}{c}-575.0 * * * \\
(162.0)\end{array}$ & & $\begin{array}{c}-956.0 * * * \\
(354.3)\end{array}$ \\
\hline Landlocked & $\begin{array}{c}-1,194 * * * \\
(285.0)\end{array}$ & & $\begin{array}{l}-893.0 \\
(772.4)\end{array}$ & $\begin{array}{c}-1,162 * * * \\
(295.5)\end{array}$ & & $\begin{array}{c}-989.1 \\
(705.7)\end{array}$ \\
\hline Infrastructure & $\begin{array}{c}-487.2^{* * *} \\
(181.8)\end{array}$ & $\begin{array}{l}-148.7 \\
(153.1)\end{array}$ & $\begin{array}{l}-182.5 \\
(154.4)\end{array}$ & $\begin{array}{c}-533.7 * * * \\
(189.4)\end{array}$ & $\begin{array}{l}-127.2 \\
(167.2)\end{array}$ & $\begin{array}{l}-188.7 \\
(165.1)\end{array}$ \\
\hline Customs & $\begin{array}{c}40.64 \\
(201.8)\end{array}$ & $\begin{array}{l}-12.52 \\
(154.6)\end{array}$ & $\begin{array}{l}-62.72 \\
(158.0)\end{array}$ & $\begin{array}{c}121.2 \\
(212.0)\end{array}$ & $\begin{array}{l}-22.00 \\
(168.2)\end{array}$ & $\begin{array}{l}-51.76 \\
(170.0)\end{array}$ \\
\hline Fragile States Index & $\begin{array}{c}9.769 * * * \\
(3.779)\end{array}$ & $\begin{array}{c}-22.28 * * \\
(9.893)\end{array}$ & $\begin{array}{c}3.409 \\
(6.831)\end{array}$ & $\begin{array}{c}-0.791 \\
(6.085)\end{array}$ & $\begin{array}{l}-21.04 * \\
(10.80)\end{array}$ & $\begin{array}{l}-2.787 \\
(8.884)\end{array}$ \\
\hline Southern Africa & $\begin{array}{c}386.4 * * \\
(190.4)\end{array}$ & & $\begin{array}{c}686.3 \\
(465.4)\end{array}$ & $\begin{array}{c}161.1 \\
(220.8)\end{array}$ & & $\begin{array}{c}324.0 \\
(480.4)\end{array}$ \\
\hline Central Africa & $\begin{array}{c}694.5^{* * *} \\
(201.5)\end{array}$ & & $\begin{array}{c}1,602 * * * \\
(467.5)\end{array}$ & $\begin{array}{c}461.8 * * \\
(232.6)\end{array}$ & & $\begin{array}{l}1,016^{*} \\
(526.9)\end{array}$ \\
\hline East Africa & $\begin{array}{l}-20.60 \\
(159.9)\end{array}$ & & $\begin{array}{c}388.9 \\
(416.2)\end{array}$ & $\begin{array}{l}-43.88 \\
(165.9)\end{array}$ & & $\begin{array}{c}219.0 \\
(387.9)\end{array}$ \\
\hline West Africa & $\begin{array}{c}-198.2 \\
(146.3)\end{array}$ & & $\begin{array}{c}162.8 \\
(384.9)\end{array}$ & $\begin{array}{c}-279.6^{*} \\
(155.7)\end{array}$ & & $\begin{array}{l}-64.05 \\
(369.6)\end{array}$ \\
\hline Constant & $\begin{array}{l}-97.54 \\
(501.9)\end{array}$ & $\begin{array}{c}3,759 * * * \\
(961.5)\end{array}$ & $\begin{array}{c}463.2 \\
(738.4)\end{array}$ & $\begin{array}{c}206.1 \\
(536.9)\end{array}$ & $\begin{array}{c}2,210 \\
(1,624)\end{array}$ & $\begin{array}{c}212.2 \\
(730.5)\end{array}$ \\
\hline Observations & 393 & 393 & 393 & 393 & 393 & 393 \\
\hline $\mathrm{R}^{2}$ & 0.776 & 0.681 & 0.730 & 0.763 & 0.690 & 0.764 \\
\hline Sargan p-value & & & & 0.000 & 0.53 & 0.38 \\
\hline $\begin{array}{l}\text { Hausman p-value } \\
\text { Year dummies }\end{array}$ & Yes & Yes & $\begin{array}{l}1.00 \\
\text { Yes }\end{array}$ & Yes & Yes & $\begin{array}{l}1.00 \\
\text { Yes }\end{array}$ \\
\hline
\end{tabular}

N.B. The Hausman P-value compares FE- 2SLS and RE- 2SLS specifications. North Africa is the reference. Standard errors in parentheses: *** $\mathrm{p}<0.01$; ${ }^{* *} \mathrm{p}<0.05$; ${ }^{*} \mathrm{p}<0.1$. For the instrumentation of the Processing time, the right hand side regression in Table 3 has been considered. Sources. See Appendix 2 
Table 3. Transport and logistics costs determinants and instrumentation of the Processing time

\begin{tabular}{|c|c|c|}
\hline & $\begin{array}{r}\text { Reg } 7 \\
\text { RE- 2SLS } \\
\end{array}$ & $\begin{array}{l}\text { Processing time } \\
\text { First stage } \\
\text { regression }\end{array}$ \\
\hline Distance & $1.683 * * *$ & $0.0251 * * *$ \\
\hline & $(0.352)$ & $(0.002)$ \\
\hline RER & $1,557 * *$ & -0.275 \\
\hline & $(608.3)$ & (7.125) \\
\hline Processing time & $33.91^{* * *}$ & \\
\hline & $(11.21)$ & \\
\hline Island & $-579.6^{* *}$ & 0.152 \\
\hline & $(272.7)$ & $(3.652)$ \\
\hline Resolving Insolvency & & $-0.245 * * *$ \\
\hline & & $(0.057)$ \\
\hline Processing time of neighbours & & $0.128 *$ \\
\hline & & $(0.070)$ \\
\hline $\log$ (population) & & $3.999 * * *$ \\
\hline & & $(0.719)$ \\
\hline Southern Africa & 62.63 & $18.84 * * *$ \\
\hline & $(378.0)$ & $(4.220)$ \\
\hline Central Africa & 758.0 & $26.51 * * *$ \\
\hline & $(465.2)$ & $(4.382)$ \\
\hline East Africa & 138.0 & $10.23 *$ \\
\hline & $(344.5)$ & (3.824) \\
\hline West Africa & -66.41 & $12.18 * * *$ \\
\hline & (330.8) & $(3.749)$ \\
\hline Constant & -651.0 & $-35.54 * * *$ \\
\hline & $(450.1)$ & $(13.76)$ \\
\hline Observations & 450 & 450 \\
\hline Wald P-value & 0.00 & 0.00 \\
\hline F-test & & $78.2 * * *$ \\
\hline R-squared & 0.78 & 0.64 \\
\hline Year Dummies & Yes & Yes \\
\hline Hausman P-value & 1.000 & \\
\hline Sargan P-value & 0.613 & \\
\hline
\end{tabular}

N.B. The right hand side column is for the instrumented variable of the Processing time that we use to explain the cost to import on the left hand side. The Hausman P-value compares FE- 2SLS and RE2SLS specifications. North Africa is the reference. Standard errors in parentheses: ${ }^{* * *} \mathrm{p}<0.01$; ${ }^{* *} \mathrm{p}<0.05$; ${ }^{*} \mathrm{p}<0.1$ 
Table 4. Transport and logistics costs:

Private management and competition in port terminals

\begin{tabular}{|c|c|c|c|}
\hline & $\begin{array}{c}\operatorname{Reg} 8 \\
\text { RE-2SLS }\end{array}$ & $\begin{array}{c}\text { Reg } 9 \\
\text { RE-2SLS }\end{array}$ & $\begin{array}{c}\text { Reg } 10 \\
\text { RE-2SLS }\end{array}$ \\
\hline Distance & $\begin{array}{c}1.697 * * * \\
(0.359)\end{array}$ & $\begin{array}{c}1.654 * * * \\
(0.327)\end{array}$ & $\begin{array}{c}1.189 * * * \\
(0.422)\end{array}$ \\
\hline RER & $\begin{array}{c}1,489 * * \\
(613.2)\end{array}$ & $\begin{array}{c}1,372 * * \\
(587.4)\end{array}$ & $\begin{array}{c}1,896^{* *} \\
(784.5)\end{array}$ \\
\hline Processing time & $\begin{array}{c}32.02 * * * \\
(11.76)\end{array}$ & $\begin{array}{c}27.00 * * * \\
(9.821)\end{array}$ & $\begin{array}{c}32.07 * * \\
(12.63)\end{array}$ \\
\hline Island & $\begin{array}{l}-524.2 * \\
(291.4)\end{array}$ & $\begin{array}{l}-346.9 \\
(277.6)\end{array}$ & $\begin{array}{l}-686.6^{*} \\
(371.7)\end{array}$ \\
\hline Private management (years) & & $\begin{array}{c}76.60 * * * \\
(19.26)\end{array}$ & \\
\hline Number of port operators & $\begin{array}{c}67.50 \\
(154.9)\end{array}$ & $\begin{array}{l}-32.44 \\
(144.4)\end{array}$ & $\begin{array}{c}88.98 \\
(231.2)\end{array}$ \\
\hline Private Presence & $\begin{array}{c}72.44 \\
(112.9)\end{array}$ & & \\
\hline Transition to private port & & & $\begin{array}{c}109.8 \\
(129.9)\end{array}$ \\
\hline Railway & $\begin{array}{c}30.31 \\
(200.7)\end{array}$ & $\begin{array}{c}220.0 \\
(188.3)\end{array}$ & $\begin{array}{c}40.26 \\
(255.7)\end{array}$ \\
\hline Southern Africa & $\begin{array}{c}152.9 \\
(421.1)\end{array}$ & $\begin{array}{c}295.7 \\
(375.1)\end{array}$ & $\begin{array}{c}288.5 \\
(461.8)\end{array}$ \\
\hline Central Africa & $\begin{array}{l}806.9 * \\
(486.2)\end{array}$ & $\begin{array}{c}892.7 * * \\
(430.5)\end{array}$ & $\begin{array}{c}710.2 \\
(570.5)\end{array}$ \\
\hline East Africa & $\begin{array}{c}162.5 \\
(370.1)\end{array}$ & $\begin{array}{c}34.66 \\
(343.9)\end{array}$ & $\begin{array}{c}293.5 \\
(465.4)\end{array}$ \\
\hline West Africa & $\begin{array}{l}-67.06 \\
(343.4)\end{array}$ & $\begin{array}{c}55.29 \\
(307.3)\end{array}$ & $\begin{array}{c}17.69 \\
(382.0)\end{array}$ \\
\hline Constant & $\begin{array}{l}-708.2 \\
(495.9)\end{array}$ & $\begin{array}{l}-455.9 \\
(434.4)\end{array}$ & $\begin{array}{l}-815.6 \\
(561.8)\end{array}$ \\
\hline Observations & 450 & 450 & 315 \\
\hline $\mathrm{R}^{2}$ & 0.78 & 0.78 & 0.66 \\
\hline Sargan P-Value & 0.72 & 0.96 & 0.96 \\
\hline Hausman P-Value & 1.00 & 1.00 & 1.00 \\
\hline Year dummies & Yes & Yes & Yes \\
\hline Number of countries & 50 & 50 & 35 \\
\hline
\end{tabular}

Sources. See Appendix 2. North Africa is the reference. Robust standard errors in parentheses ${ }^{* * *} \mathrm{p}<0.01,{ }^{* *} \mathrm{p}<0.05$, ${ }^{*} \mathrm{p}<0.1$. 
Table 5. Sensitivity of regression results to regions and per capita income levels

\begin{tabular}{|l|ccccc|}
\hline & Reg 11 & Reg 12 & Reg 13 & Reg 14 & Reg 15 \\
& RE-2SLS & RE-2SLS & RE-2SLS & RE-2SLS & RE-2SLS \\
& & Less NAF & Less NAF/CAF & LIC & MIC \\
\hline Distance & $1.683^{* * *}$ & $1.731^{* * *}$ & $1.623^{* * *}$ & $1.784^{* * *}$ & $2.036^{* * *}$ \\
RER & $(0.352)$ & $(0.358)$ & $(0.314)$ & $(0.563)$ & $(0.510)$ \\
& $1,557^{* *}$ & $1,496^{* *}$ & $1,976^{* * *}$ & $2,171^{* *}$ & $1,815^{* *}$ \\
Processing time & $(608.3)$ & $(638.8)$ & $(552.0)$ & $(935.4)$ & $(914.3)$ \\
& $33.91^{* * *}$ & $31.87^{* * *}$ & $36.59 * * *$ & $38.92^{* *}$ & $26.96 * *$ \\
Island & $(11.21)$ & $(11.23)$ & $(10.77)$ & $(15.79)$ & $(10.63)$ \\
& $-579.6 * *$ & $-601.3^{* *}$ & -163.3 & 11.52 & $-901.6 * * *$ \\
Southern Africa & $(272.7)$ & $(282.2)$ & $(287.8)$ & $(518.7)$ & $(273.8)$ \\
& 62.63 & 136.9 & 122.8 & 255.4 & -34.40 \\
Central Africa & $(378.0)$ & $(249.2)$ & $(217.2)$ & $(730.3)$ & $(379.4)$ \\
& 758.0 & $861.0 * * *$ & & & $863.9 * *$ \\
East Africa & $(465.2)$ & $(308.0)$ & & & $(393.5)$ \\
& 138.0 & 201.0 & 124.6 & -84.57 & 353.7 \\
West Africa & $(344.5)$ & $(218.5)$ & $(191.9)$ & $(319.1)$ & $(353.4)$ \\
& -66.41 & & & & 116.7 \\
Constant & $(330.8)$ & & & & $(327.9)$ \\
& -651.0 & -658.0 & $-1,004^{*}$ & $-1,128 *$ & -467.7 \\
& $(450.1)$ & $(524.2)$ & $(517.3)$ & $(673.5)$ & $(468.4)$ \\
\hline Observations & 450.00 & 414.00 & 342.00 & 216.00 & 234.00 \\
R ${ }^{2}$ & 0.78 & 0.78 & 0.76 & 0.85 & 0.60 \\
Sargan p-value & 0.64 & 0.57 & 0.85 & 0.51 & 0.65 \\
Hausman p-value & 1.00 & 1.00 & 1.00 & 1.00 & 1.00 \\
Year dummies & Yes & Yes & Yes & Yes & Yes \\
\hline
\end{tabular}

Sources. See Appendix 2. Reg 11 is the same as Reg 6, Table 3. In Reg 12, we drop the North African countries (NAF) and in Reg 13, we also remove Central African countries (NAF, CAF). In Reg 14 and Reg 15, we focus on low (LIC) and middle-income (MIC) countries. Robust standard errors in parentheses $* * *$ $\mathrm{p}<0.01,{ }^{* *} \mathrm{p}<0.05,{ }^{*} \mathrm{p}<0.1$. 
Table 6. Simulation of potential savings on the costs to import (2006-2014) (From regression 6, Table 3)

\begin{tabular}{|c|cc|cc|cc|c|c|}
\hline & \multicolumn{4}{|c|}{ Average 2006-2010 } & \multicolumn{4}{c|}{ Average 2010-2014 } \\
\cline { 2 - 9 } & \multicolumn{2}{|c|}{ RER } & Time & \multicolumn{2}{|c|}{ Total } & RER & Time & \multicolumn{2}{c|}{ Total } \\
\cline { 2 - 9 } & \multicolumn{2}{|c|}{ Dollars } & Dollars & $(\%)$ & \multicolumn{2}{|c|}{ Dollars } & Dollars & $(\%)$ \\
\hline Northern Africa & 0 & 83 & 83 & 10 & 0 & 135 & 135 & 12 \\
- Algeria & 0 & 77 & 77 & 5,3 & 0 & 401 & 401 & 30 \\
West Africa & 14 & 459 & 473 & 34 & 20 & 491 & 511 & 33 \\
-Nigeria & 0 & 896 & 896 & 75 & 40 & 832 & 872 & 58 \\
East Africa & 30 & 328 & 358 & 21 & 29 & 195 & 224 & 14 \\
- Mozambique & 182 & 478 & 660 & 54 & 130 & 463 & 593 & 39 \\
Central Africa & 64 & 670 & 734 & 31 & 87 & 817 & 905 & 37 \\
- Congo DRC & 131 & 1,267 & 1,398 & 46 & 199 & 1,392 & 1,591 & 43 \\
Southern Africa & 40 & 291 & 331 & 17 & 86 & 337 & 422 & 15 \\
- Angola & 192 & 1,297 & 1,489 & 69 & 357 & 1,157 & 1,513 & 54 \\
\hline
\end{tabular}

Results are from $\operatorname{Reg} 7$, Table 3 or Reg 11, Table 5. Percentages are relative to the average domestic cost to import. Time reflects what can be earned with a more efficient Processing time. Results by country are given in Appendix 4. RER is the real exchange rate. Sources, Appendix 2. 


\section{Appendices}

Appendix 1. Africa by region and income level countries

\begin{tabular}{|c|c|c|c|c|}
\hline Southern Africa & Central Africa & East Africa & West Africa & $\begin{array}{l}\text { North } \\
\text { Africa }\end{array}$ \\
\hline $\begin{array}{l}\text { South African } \\
\text { Rep } \\
\text { Angola } \\
\text { Botswana } \\
\text { Lesotho } \\
\text { Namibia } \\
\text { Swaziland } \\
\text { Zambia } \\
\text { Zimbabwe }\end{array}$ & $\begin{array}{l}\text { Central African Rep } \\
\text { Cameroon } \\
\text { Congo } \\
\text { Gabon } \\
\text { Equatorial Guinea } \\
\text { R.D of Congo } \\
\text { Sao Tomé \& } \\
\text { Principe } \\
\text { Chad }\end{array}$ & $\begin{array}{l}\text { Burundi } \\
\text { Comoros } \\
\text { Djibouti } \\
\text { Ethiopia } \\
\text { Kenya } \\
\text { Madagascar } \\
\text { Malawi } \\
\text { Mauritius } \\
\text { Mozambique } \\
\text { Rwanda } \\
\text { Seychelles } \\
\text { Sudan } \\
\text { Tanzania } \\
\text { Uganda }\end{array}$ & $\begin{array}{l}\text { Benin } \\
\text { Burkina-Faso } \\
\text { Cape Verde } \\
\text { Côte d'Ivoire } \\
\text { Gambia } \\
\text { Ghana } \\
\text { Guinea } \\
\text { Guinea -Bissau } \\
\text { Liberia } \\
\text { Mali } \\
\text { Mauritania } \\
\text { Niger } \\
\text { Nigeria } \\
\text { Senegal } \\
\text { Sierra Leone } \\
\text { Togo }\end{array}$ & $\begin{array}{l}\text { Algeria } \\
\text { Egypt } \\
\text { Morocco } \\
\text { Tunisia }\end{array}$ \\
\hline
\end{tabular}

Note. Income level categories. Bold and italics relate to upper and lower middle-income countries as defined by the World Bank in June 2018. The other countries are low-income economies. 
Appendix 2. Domestic transport and logistics in Africa (2014)

\begin{tabular}{|c|c|c|c|c|c|c|c|}
\hline Countries & $\begin{array}{c}\text { Distance } \\
\text { (Km) }\end{array}$ & $\begin{array}{c}\text { Misalignment } \\
(\%)\end{array}$ & RER & $\begin{array}{l}\text { Processing } \\
\text { time }\end{array}$ & $\begin{array}{c}\text { Years with a } \\
\text { private port } \\
\text { operator }\end{array}$ & $\begin{array}{c}\text { Nbr of } \\
\text { private port } \\
\text { operators }\end{array}$ & $\begin{array}{c}\text { Port } \\
\text { of arrival }\end{array}$ \\
\hline Angola & 27 & +22 & 0.71 & 42.3 & 8 & 1 & Luanda \\
\hline Burundi & 1419 & -8 & 0.37 & 8.8 & 15 & 1 & Dar-es-Salaam \\
\hline Benin & 6 & -1 & 0.45 & 26.8 & 6 & 2 & Cotonou \\
\hline Burkina Faso & 944 & -2 & 0.42 & 24.2 & 11 & 3 & Abidjan \\
\hline Botswana & 917 & -9 & 0.45 & 10.9 & 0 & 1 & Durban \\
\hline Central African Republic & 1404 & +14 & 0.59 & 18.1 & 11 & 2 & Douala \\
\hline Côte d'Ivoire & 23 & +2 & 0.47 & 33.4 & 11 & 3 & Abidjan \\
\hline Cameroon & 15 & +1 & 0.47 & 24.6 & 11 & 2 & Douala \\
\hline Congo, DRC & 327 & +15 & 0.58 & 54.4 & 0 & 1 & Matadi \\
\hline Congo, Rep & 560 & +3 & 0.50 & 39.3 & 7 & 2 & Pointe Noire \\
\hline Comoros & 2 & +11 & 0.57 & 23.9 & 3 & 1 & Moroni \\
\hline Cabo Verde & 6 & +7 & 0.57 & 17.8 & 0 & 1 & Praia \\
\hline Djibouti & 11 & +8 & 0.55 & 17.7 & 9 & 2 & Djibouti \\
\hline Algeria & 7 & -12 & 0.39 & 26.8 & 7 & 1 & Alger \\
\hline Egypt, Arab Rep, & 224 & -17 & 0.32 & 9.1 & 11 & 2 & Alexandria \\
\hline Ethiopia & 864 & -7 & 0.38 & 21.3 & 9 & 2 & Djibouti \\
\hline Gabon & 18 & +2 & 0.55 & 21.5 & 8 & 1 & Libreville \\
\hline Ghana & 36 & -11 & 0.35 & 41.0 & 11 & 2 & Tema \\
\hline Guinea & 27 & -1 & 0.44 & 30.3 & 4 & 2 & Conakry \\
\hline Gambia, The & 2 & -18 & 0.27 & 18.9 & 0 & 1 & Banjul \\
\hline Guinea-Bissau & 8 & -2 & 0.44 & 21.8 & 0 & 1 & Bissau \\
\hline Equatorial Guinea & 7 & -3 & 0.58 & 43.8 & 0 & 1 & Malabo \\
\hline Kenya & 481 & 0 & 0.46 & 13.4 & 7 & 1 & Mombasa \\
\hline Liberia & 10 & +9 & 0.54 & 28.7 & 4 & 1 & Monrovia \\
\hline Lesotho & 549 & -4 & 0.41 & 18.6 & 0 & 1 & Durban \\
\hline Morocco & 337 & -6 & 0.42 & 6.1 & 8 & 2 & Tangiers \\
\hline Madagascar & 356 & -14 & 0.31 & 11.6 & 10 & 1 & Toamasina \\
\hline Mali & 1093 & -4 & 0.42 & 6.3 & 8 & 2 & Dakar \\
\hline Mozambique & 14 & +9 & 0.55 & 24.6 & 7 & 1 & Maputo \\
\hline Mauritania & 16 & -11 & 0.35 & 37.6 & 7 & 1 & Nouakchott \\
\hline Mauritius & 5 & -4 & 0.53 & 8.9 & 0 & 1 & Port Louis \\
\hline Malawi & 948 & -14 & 0.31 & 14.1 & 7 & 1 & Beira \\
\hline Namibia & 394 & +2 & 0.53 & 9.6 & 0 & 1 & Walvis Bay \\
\hline Niger & 1021 & 0 & 0.45 & 35.2 & 6 & 2 & Cotonou \\
\hline Nigeria & 11 & +6 & 0.52 & 32.7 & 9 & 3 & Apapa Tin Can \\
\hline Rwanda & 1418 & -4 & 0.42 & -7.2 & 15 & 1 & Dar-es-Salaam \\
\hline Sudan & 831 & +2 & 0.49 & 24.2 & 0 & 1 & Port Soudan \\
\hline Senegal & 17 & -1 & 0.45 & 14.5 & 8 & 2 & Dakar \\
\hline Sierra Leone & 8 & -6 & 0.40 & 29.8 & 4 & 1 & Freetown \\
\hline South Sudan & 1338 & +9 & 0.55 & 94.9 & 7 & 1 & Mombasa \\
\hline São Tomé and Príncipe & 3 & +13 & 0.60 & 27.9 & 0 & 1 & Sao \\
\hline Swaziland & 539 & -8 & 0.42 & 8.8 & 0 & 1 & Durban \\
\hline Seychelles & 0 & -5 & 0.59 & 17.0 & 0 & 1 & Port Victoria \\
\hline Chad & 1642 & +1 & 0.47 & 54.9 & 11 & 2 & Douala \\
\hline Togo & 8 & -1 & 0.45 & 28.8 & 5 & 3 & Lome \\
\hline Tunisia & 13 & -12 & 0.38 & 16.6 & 0 & 1 & Rades \\
\hline Tanzania & 5 & -8 & 0.38 & 30.9 & 15 & 1 & Dar-es-Salaam \\
\hline Uganda & 1145 & -5 & 0.41 & 2.9 & 7 & 1 & Mombasa \\
\hline South Africa & 570 & -3 & 0.50 & 6.0 & 0 & 1 & Durban \\
\hline
\end{tabular}




\begin{tabular}{|l|l|l|l|l|l|l|l|} 
Zambia & 1051 & -1 & 0.45 & 25,4 & 7 & 1 & Durban \\
\hline Zimbabwe & 1678 & +5 & 0.52 & 27,0 & 7 & 1 & Durban \\
\hline
\end{tabular}

Sources. Cost to import, distance, the port of arrival, and time to import from which the processing time is calculated are from the Doing business, World Bank, different years. For landlocked economies, the port referred to is that of the Doing Business. Real Exchange Rates (RER) are from the World Bank's World Development Indicators with adjustments for resource natural rents given by rents. Adjustment for rents and the productivity bias are calculated from the information of the OSD-FERDI website (https://competitivite.ferdi.fr). The Logistics Performance Index (LPI) and its components: Customs or Infrastructure have been downloaded from the World Bank website (https://lpi.worldbank.org). The Fragile States Index refers to the Fund for Peace (http://fundforpeace.org/fsi). Private port operators, number of port operators are gleaned from different sources including Proparco, the French Development Agency (AFD): Secteur Privé et développment, le secteur portuaire en Afrique, plein cap sur le développement, March-May 2017. The database is available on request from the author.

\section{Appendix 3. Regression of Price level ratio of PPP conversion factor to market exchange rate on per capita GDP (2006-2014, 190 countries)}

\begin{tabular}{|l|c|}
\hline Variables & Linear model \\
\hline & \\
[GDP - Rents] per capita & $1.23 \mathrm{e}-05^{* * *}$ \\
& $(2.05 \mathrm{e}-07)$ \\
& $0.00310^{* *}$ \\
& $(0.00152)$ \\
Year dummies & $0.427 * * *$ \\
Constant & $(0.00880)$ \\
& \\
\hline Observations & 1,629 \\
R-squared & 0.690 \\
\hline
\end{tabular}

N.B. Robust standard errors in parentheses $* * * \mathrm{p}<0.01, * * \mathrm{p}<0.05, * \mathrm{p}<0.1$. Nominal per capita GDPs from which total natural rents are removed are in current dollars. Sources. From the World Development Indicators, World Bank. 
Appendix 4. By country potential savings on domestic costs of transport and logistics

\begin{tabular}{|c|c|c|c|c|c|c|c|c|}
\hline & \multicolumn{4}{|c|}{ Trade cost savings $2006-2010$} & \multicolumn{4}{|c|}{ Trade cost savings $2010-2014$} \\
\hline & \multirow{2}{*}{\begin{tabular}{|c|} 
RER \\
Amount
\end{tabular}} & \multirow{2}{*}{$\frac{\text { Processing time }}{\text { Amount }}$} & \multicolumn{2}{|c|}{ Total cost saved } & \multirow{2}{*}{\begin{tabular}{|c|} 
RER \\
Amount
\end{tabular}} & \multirow{2}{*}{$\frac{\text { Processing time }}{\text { Amount }}$} & \multicolumn{2}{|c|}{ Total cost saved } \\
\hline & & & Amount & $(\%)$ & & & Amount & $(\%)$ \\
\hline Angola & 191.9 & 1297.0 & 1488.8 & 69.4 & 356.5 & 1156.7 & 1513.3 & 54.4 \\
\hline Burundi & 0.0 & 465.4 & 465.4 & 11.5 & 0.0 & 150.3 & 150.3 & 3.7 \\
\hline Benin & 0.0 & 595.1 & 595.1 & 47.1 & 0.0 & 578.6 & 578.6 & 39.0 \\
\hline Burkina Faso & 0.0 & 311.5 & 311.5 & 8.1 & 0.0 & 354.4 & 354.4 & 8.5 \\
\hline Botswana & 0.0 & 0.0 & 0.0 & 0.0 & 0.0 & 72.4 & 72.4 & 2.2 \\
\hline Central Africa Rep & 103.3 & 309.2 & 412.5 & 8.9 & 135.6 & 352.1 & 487.7 & 8.6 \\
\hline Côte d'Ivoire & 0.0 & 758.0 & 758.0 & 36.1 & 15.9 & 719.5 & 735.3 & 32.3 \\
\hline Cameroon & 7.9 & 426.0 & 433.9 & 21.1 & 3.6 & 394.3 & 397.9 & 17.5 \\
\hline Congo (DRC) & 130.7 & 1267.4 & 1398.1 & 46.0 & 199.3 & 1391.7 & 1591.0 & 42.8 \\
\hline \begin{tabular}{|l|} 
Congo \\
\end{tabular} & 95.8 & 924.5 & 1020.3 & 43.4 & 127.0 & 1096.2 & 1223.3 & 21.2 \\
\hline Comoros & 149.4 & 132.4 & 281.8 & 25.0 & 162.9 & 358.4 & 521.2 & 42.4 \\
\hline Cabo Verde & 176.5 & 37.3 & 213.7 & 22.1 & 136.5 & 151.3 & 287.8 & 31.1 \\
\hline \begin{tabular}{|l} 
Djibouti \\
\end{tabular} & 48.7 & 96.1 & 144.8 & 17.4 & 107.6 & 146.9 & 254.5 & 27.9 \\
\hline Algeria & 0.0 & 77.0 & 77.0 & 5.3 & 0.0 & 401.4 & 401.4 & 30.3 \\
\hline Egypt & 0.0 & 69.1 & 69.1 & 6.3 & 0.0 & 0.0 & 0.0 & 0.0 \\
\hline Ethiopia & 0.0 & 0.0 & 0.0 & 0.0 & 0.0 & 269.6 & 269.6 & 10.1 \\
\hline Gabon & 98.1 & 50.3 & 148.4 & 8.9 & 108.3 & 276.3 & 384.6 & 19.3 \\
\hline Ghana & 0.0 & 873.6 & 873.6 & 98.7 & 0.0 & 836.8 & 836.8 & 65.3 \\
\hline Guinea & 0.0 & 381.4 & 381.4 & 28.7 & 0.0 & 600.6 & 600.6 & 40.6 \\
\hline Gambia & 0.0 & 98.4 & 98.4 & 11.8 & 0.0 & 215.9 & 215.9 & 29.9 \\
\hline Guinea- Bissau & 0.0 & 127.0 & 127.0 & 6.8 & 0.0 & 285.2 & 285.2 & 13.4 \\
\hline Equatorial Guinea & 0.0 & 763.7 & 763.7 & 46.8 & 0.0 & 1038.9 & 1038.9 & 64.0 \\
\hline Kenya & 0.0 & 322.2 & 322.2 & 14.4 & 0.0 & 0.0 & 0.0 & 0.0 \\
\hline Liberia & 0.0 & 396.5 & 396.5 & 33.3 & 107.3 & 534.4 & 641.6 & 48.4 \\
\hline \begin{tabular}{|l|} 
Lesotho \\
\end{tabular} & 13.5 & 493.4 & 506.9 & 38.8 & 20.9 & 326.1 & 347.0 & 19.9 \\
\hline Morocco & 0.0 & 1.9 & 1.9 & 0.1 & 0.0 & 0.0 & 0.0 & 0.0 \\
\hline Madagascar & 0.0 & 439.5 & 439.5 & 34.3 & 0.0 & 48.3 & 48.3 & 3.0 \\
\hline Mali & 0.0 & 515.7 & 515.7 & 17.9 & 0.0 & 0.0 & 0.0 & 0.0 \\
\hline Mozambique & 182.0 & 477.7 & 659.8 & 53.6 & 130.4 & 463.0 & 593.4 & 38.9 \\
\hline Mauritania & 0.0 & 662.5 & 662.5 & 47.3 & 0.0 & 847.8 & 847.8 & 55.7 \\
\hline Mauritius & 0.0 & 0.0 & 0.0 & 0.0 & 0.0 & 0.0 & 0.0 & 0.0 \\
\hline Malawi & 0.0 & 308.0 & 308.0 & 12.3 & 0.0 & 242.3 & 242.3 & 9.4 \\
\hline Namibia & 82.0 & 0.0 & 82.0 & 5.1 & 135.4 & 0.0 & 135.4 & 7.3 \\
\hline Niger & 0.0 & 649.9 & 649.9 & 21.4 & 0.7 & 835.3 & 836.0 & 23.7 \\
\hline \begin{tabular}{|l|} 
Nigeria \\
\end{tabular} & 0.0 & 895.8 & 895.8 & 74.6 & 40.1 & 831.9 & 872.0 & 58.3 \\
\hline Rwanda & 0.0 & 739.7 & 739.7 & 18.0 & 0.0 & 0.0 & 0.0 & 0.0 \\
\hline Sudan & 0.0 & 861.4 & 861.4 & 42.0 & 0.0 & 366.8 & 366.8 & 12.6 \\
\hline \begin{tabular}{|l|} 
Senegal \\
\end{tabular} & 49.2 & 165.6 & 214.7 & 11.1 & 14.2 & 39.8 & 54.0 & 2.7 \\
\hline Sierra Leone & 0.0 & 466.1 & 466.1 & 43.1 & 0.0 & 529.4 & 529.4 & 35.9 \\
\hline Sao Tome-Principe & 0.0 & 301.0 & 301.0 & 52.2 & 78.0 & 506.7 & 584.6 & 101.3 \\
\hline Swaziland & 0.0 & 0.0 & 0.0 & 0.0 & 0.0 & 16.8 & 16.8 & 0.7 \\
\hline Seychelles & 37.3 & 0.0 & 37.3 & 4.3 & 0.0 & 143.1 & 143.1 & 17.2 \\
\hline Chad & 77.9 & 1318.2 & 1396.1 & 23.9 & 47.0 & 1483.1 & 1530.1 & 19.0 \\
\hline Togo & 0.0 & 415.3 & 415.3 & 43.9 & 0.0 & 502.2 & 502.2 & 44.6 \\
\hline Tunisia & 0.0 & 181.9 & 181.9 & 28.6 & 0.0 & 138.3 & 138.3 & 16.1 \\
\hline Tanzania & 0.0 & 519.7 & 519.7 & 46.4 & 0.0 & 545.6 & 545.6 & 36.0 \\
\hline Uganda & 0.0 & 235.9 & 235.9 & 8.0 & 0.0 & 0.0 & 0.0 & 0.0 \\
\hline South Africa & 31.0 & 0.0 & 31.0 & 2.4 & 79.6 & 115.3 & 194.8 & 10.7 \\
\hline Zambia & 0.0 & 385.9 & 385.9 & 13.1 & 18.3 & 489.8 & 508.1 & 9.9 \\
\hline Zimbabwe & 0.0 & 150.2 & 150.2 & 5.0 & 76.0 & 515.2 & 591.2 & 11.3 \\
\hline
\end{tabular}




\section{References}

Adam. C., \& Bevan. D. (2014). Public Investment, Public Finance, and Growth: The Impact of Distortionary Taxation, Recurrent Costs, and Incomplete Appropriability, IMF Working Paper WP/14/73

African Development Bank. (2015). Problématique de la facilitation du transport en Afrique de l'Ouest et Plan d’actions, Département des Transports, du Développement Urbain et des TIC, Abidjan.

Alfonso. H and S. Vergara. (2019). Exporters in Africa, What Role for Trade Costs? Munich Personal RepEc Archive (MPRA), September.

Arvis, J.F., Raballand.G., \&,. Marteau, J.F. (2010). The Cost of Being Landlocked: Logistics Costs and Supply Chain Reliability. Washington, DC: World Bank.

Bhattacharya, S., \&. Collier. P. (2011). Public Capital in Resource Rich Economies: Is there a curse? CSAE Working Paper WPS/2011-14.

Balassa, B. (1964). The purchasing-power parity doctrine: a reappraisal. The Journal of Political Economy, vol. 72, n 6, 584-596.

Christ, M., \& Ferrantino, M.J. (2011). Land Transport for Export: The Effects of Cost, Time, and Uncertainty in Sub-Saharan Africa. World Development, Vol. 39, No. 10, pp. 1749-1759, 2011.

Clark, X., Dollar, D., \& Micco, A. (2004). Port efficiency, maritime transport costs, and bilateral trade. Journal of Development Economics, 75, 417-450.

Devarajan, S. (2012). Why does cargo spend week in Sub Saharan African ports, lesson from six countries. Forward, in Raballand, G, Refas, S, Beuran, M \& Isik, G, World Bank, Washington D.C

Eifert. B, Gelb. A., \& Ramachandran, V. (2008). The Cost of Doing Business in Africa: Evidence from Enterprise Survey Data? World Development, Vol. 36, No. 9, pp. 1531-1546,

Feenstra, R .C. (1998). Integration of Trade and disintegration of production in the global economy. The Journal of Economic Perspectives, Volume 12, Number 3

Foster, V., \& Briceno-Garmendia, C. (2010). Africa's Infrastructure: a Time for Transition, World Bank, Washington DC.

François, J., \& Manchin, M. (2013). Institutions, Infrastructure, and Trade, World Development Vol. 46, pp. 165-175, 2013

Freund, C; Hallward-Driemeier. M., \& Rijkers. B. (2014). Deals and Delays, Firm-level Evidence on Corruption and Policy Implementation Times, The World Bank, Development Research Group Finance and Private Sector Development Team and Trade and International Integration Team, June 
Gwilliman, K. (2011). Africa's transport infrastructure, Mainstreaming, Maintenance and Management? The World Bank, 576 p

Hoekman, B \&., Nicita, A. (2011). Trade Policy, Trade Costs, and Developing Country Trade? World Development Vol. 39, No. 12, pp. 2069-2079

Hausman, J. (1978). Specification tests in econometrics, Econometrica, vol. 46, issue 6, 1251-1271

Hallward-Driemeier, M., \& Pritchett, L.(2015). How Business is Done in the Developing World: Deals versus Rules. The Journal of Economic Perspectives, Volume 29, Number 3

Hummels, D.L., \& Schaur, G. (2013). Time as a Trade Barrier. American Economic Review, 103 (7): 2935-59.

IMF. (2015). Making Public Investment More Efficient, IMF Staff Report, Washington.

Iwanow, T., \& Kirkpatrick, C. (2009). Trade Facilitation and Manufactured Exports: Is Africa Different? World Development, 2009, vol. 37, issue 6, 1039-1050.

Jedwab, R., \& A. Storeygard. (2017). Economic and Political Factors in Infrastructure Investment: Evidence from Railroads and Roads in Africa 1960-2015, Institute for International Economic Policy Working Paper series, Elliott School of International Affairs, The George Washington University

Kunaka, C., Raballand. G., \& Fitzmaurice, M.(2016). How trucking services have improved and may contribute to economic development, the case of East Africa. WIDER Working Paper 2016/152, December, Helsinki

Limao, N., \& Venables, A. (2001). Infrastructure, geographical disadvantage, transport costs and trade. The World Bank Economic Review, 15(3), 451-479.

Lindsay, C.M. (1976). A Theory of Government enterprise. Journal of Political Economy, 84/5 October 1061-1077.

Portugal-Perez, A., \& Wilson, J. S. (2012). Export performance and trade facilitation reform: Hard and soft infrastructure. World Development, 40(7), 1295-1307.

Osborne. T, Pachon, M.C., \& Araya, G.E. (2014). What Drives the High Price of Road Freight Transport in Central America? The World Bank, Latin America and the Caribbean Region Sustainable Development Department, WPS6844, April 2014.

PROPARCO. (2017). Secteur Privé et développment, le secteur portuaire en Afrique, plein cap sur le développement. (Group of the French Agency of Development- AFD), Mars-Mai 2017.

Raballand, G., Refas, S., Beuran, M., \& Isik, G. (2012). Why does cargo spend week in Sub Saharan African ports, lesson from six countries? World Bank, Washington D.C

Raballand, G., \& Teravaninthorn. S. (2009). Transport prices and costs in Africa: A review of the international corridors. Washington, DC: The World Bank. 
Radelet, S., \& Sachs, J. (1998). Shipping costs, manufactured exports, and economic growth. Presented at American Economic Association Annual Meeting. http://www.earth.columbia.edu /sitefiles/File/about/ director/pubs/shipcost.pdf.

Rodrik, D. (2008). The Real Exchange Rate and Economic Growth. Brookings Papers on Economic Activity (Fall), vol 2, 365-412

Sequeira, S., \& Djankov, S. (2014). Corruption and firm behavior: evidence from African ports Journal of International Economics, 94 (2). 277-294.

Stock J. H.\& Yogo, M. (2005). Testing for weak instruments in linear IV regression, in Stock J. H. et Andrews D. W. K. (eds), Identification and Inference for Econometric Models: Essays in Honor of T.J. Rothenberg, Cambridge University Press.

World Bank. (2007). Port Reform Toolkit, PPIAF, 2nd Edition, Washington

McMillan, M., Rodrik, D., \& Verduzco-Gallo. I. (2014). Globalization, Structural Change, and Productivity Growth, with an Update on Africa. World Development, Vol. 63, 11-32

World Bank. 2014. Connecting to Compete- Trade Logistics in the Global Economy. Washington, DC: The World Bank.

i The Fragile States Index is based on a conflict assessment framework, designed to measure vulnerability in pre-conflict, active conflict and post-conflict situations. The methodology can be found at //fundforpeace.org/fsi/indicators/

ii The Hausman-Wu (1978) test about potential endogeneity of the processing time and the RER were implemented. Endogeneity is not rejected only for the former variable. Empirical results of the test are not incorporated in the text, but are provided on request.

iii The country of transit contributes to the price of the imported container, meaning that time spent in the port or along the corridor can be a source of endogeneity.

iv Central Africa has very high transport and logistics costs. In Cameroon, the distance between the port of Douala and the capital city (Yaoundé), $230 \mathrm{~km}$, is relatively short, and transport of containers by rail is marginal. It is more developed for longer trips to the hinterland (Chad and Central African Republic), but service quality is poor. In Gabon, Libreville is close to the port of Owendo. However, 95\% of containers from Libreville to Franceville go by rail. In the Democratic Republic of Congo (DRC), Katanga province receives container traffic from South Africa, Namibia and Mozambique. Containers move up the Congo and Kasaï rivers to Ilebo, whence they proceed to Katanga by rail. 